Третяк Т.О. Процедури участі громадськості у прийнятті рішень щодо видів діяльності, що мають...

DOI: $10.36695 / 2219-5521.2 .2019 .28$

УДК 349.41:347.2](477)(02)

\title{
T.O. ТРЕТЯК
}

Тарас Олексійович Третяк, кандидат юридичних наук, доцент Київського національного університету імені Тараса Шевченка*

ORCID: 0000-0002-5221-1366

\section{ПРОЦЕДУРИ УЧАСТІ ГРОМАДСЬКОСТІ У ПРИЙНЯТТІ РІШЕНЬ ЩОДО ВИДІВ ДІЯЛЬ- НОСТІ, ЩО МАЮТЬ АБО МОЖУТЬ МАТИ НЕГАТИВНИЙ ВПЛИВ НА ДОВКІЛЛЯ ЯК ЗАСОБИ ВСТАНОВЛЕННЯ ПРАВИЛ ДОБРОСУСІДСТВА}

Досвід застосування процедур участі громадськості у процесі прийняття рішень, які дозволяють і встановлюють умови для здійснення екологічно-шкідливої діяльності, свідчить, що їх потенціал залишається не достатньо використаним. Належне використання цих процедур дасть змогу підвищити ефективність охорони права власності від порушень, що $є$ результатом негативного впливу від промислового устаткування, а також запобігти зайвим витратами, які змушені нести підприємці у зв'язку з конфліктами з громадськістю, що зазнає негативного впливу від експлуатації екологічно-шкідливого устаткування.

У зв'язку із зазначеним метою цієї статті є дослідити правову природу процедур участі громадськості у зазначених процедурах, що допоможе більш повно використовувати їх потенціал.

Вимоги щодо обсягів впливу на чужу земельну ділянку встановлюються також у ході процедур прийняття рішень, що спрямовані на обмеження негативного впливу на довкілля. До таких процедур належать: процедура оцінки впливу на довкілля (далі - процедура ОВД); процедура видачі дозволу на викиди забруднювальних речовин стаціонарними джерелами; процедура стратегічної екологічної оцінки. Обмежувати значення цих процедур лише захистом права власників сусідніх земельних ділянок було б безпідставним звуженням їх призначення, однак заперечувати їх роль як процедур, в яких визначається межа дозволеного впливу на сусідню земельну ділянку, на наш погляд, також немає підстав.

Про зв'язок права власності та інших прав на земельну ділянку із зазначеними вище процедурами, як правило, не згадують ні в підручниках 3 екологічного права ${ }^{1,2,3}$ ні в підручниках із земельного права ${ }^{4,5,6}$. В окремих роботах лише міститься судження, з яких можна зробити висновок про можливість такого зв'язку. Наприклад, в одній із своїх робіт М.М. Брінчук звертає увагу на те, що «[в] рамках реалізації конституиійного права кожного на сприятливе довкілля громадяни заінтересовані і одночасно мають право брати участь у процедурі ОВД [процедурі оцінки впливу на довкілля] та оцінювати ї̈ результати»7. Створення екологічно небезпечної ситуації шляхом забруднення чужої земельної ділянки $\epsilon$, поза всякими сумнівами, порушенням права власності на земельну ділянку, тому це твердження дає підстави вважати, що право на участь у прийнятті еколого значимих рішень грунтується, поряд з правом на екологічну безпеку, також і на праві власності та деяких інших правах на земельні ділянки.

А.М. Мірошниченко включав Директиву 85/337/EЕC від 26 червня 1985 р. про оцінку впливу деяких публічних та приватних проектів на довкілля [на сьогодні втратила чинність] до складу актів, що містить норми земельно-правового характеру8. На думку В.І. Андрейцева, до складу організаційно-превентивних заходів забезпечення екологічної безпеки належить «[о]бговорення населенням проектів екологічно небез-

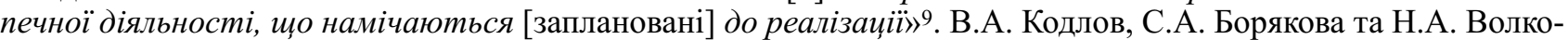
ва до правопорушень, що $є$ підставою для застосування негаторного позову, включають перешкоди екологічного характеру (наприклад, викиди забруднювальних речовин у атмосферне повітря чи шкідливий фізичний вплив на нього без спеціального дозволу) ${ }^{10}$.

Тісний зв'язок між обов'язком не спричиняти невиправданих незручностей для чужої власності (nuisance) з еколого-правовим регулюванням екологічно небезпечної діяльності підкреслював у своїх роботах Вільям Роджерса. На його думку, «[т]еорія усунення невиправданих перешкод ... $\epsilon$ загально-правовою підвалиною (common law backbone) сучасного екологічного та енергетичного права» ${ }^{11}$. На зв'язок між регулювання екологічно шкідливої діяльності та реалізацією права власності на земельні ділянки звертали увагу також і інші автори ${ }^{12}$.

Попри теоретичне і практичне значення цих положень вони залишаються лише membra disjecta (розрізненими частинами), між тим, той факт, що процедури видачі прийняття адміністративних рішень, які встановлюють умови екологічно небезпечної діяльності є інструментами реалізації права власності та деяких інших прав на земельну ділянку має надзвичайно важливе практичне і теоретичне значення. Саме ця особливість зазначених процедур дає змогу встановити і правові наслідки порушення вимог цих процедур, і роль осіб, на яких буде впливати або може впливати планована діяльність.

(C) Т.О. Третяк, 2019

${ }^{*}$ Taras Tretiak, Ph.D. in Law, Associate professor, Associate professor of Taras Shevchenko National University of Kyiv 


\section{Припис «аd qиод daтпит» як історичний попередник дозвільних процедур, що обмежують негативний вплив певних видів діяльності}

В українське законодавство велика кількість процедур участі громадськості у процесі прийняття рішень, якими встановлюються умови екологічно небезпечної діяльності, були запозичена з іноземного законодавства. Наведені обставини роблять необхідним звернутися до історії виникнення таких процедур у тих країнах, де ці процедури органічно утворилася з уже відомих інститутів права. Прототипом, наприклад, процедури ОВД була у Великій Британії процедура видачі припису короля «ad quod damnum» (лат. - відповідно до завданої шкоди). Для здійснення будь-яких публічних робіт потрібно було отримати припис «ad quod damnum» від короля. Цим приписом король надавав певного привілею (наприклад, право торгувати чи дозвіл на відчуження нерухомого майна), одночасно цей припис видавався для того, щоб визначити, чи надання такого привілею не завдасть шкоди третім особам. Кожна особа, що планувала здійснювати публічні роботи (наприклад, осушення боліт, будівництво каналу тощо) повинна була отримати цей припис ${ }^{13,14}$.

В одному із збірників правових положень та вимог справедливості Великої Британії XVIII ст. таким чином описано застосування припису «ad quod damnum» «[я]кщо буде старовинна канава чи канал, щяо бере свій початок від моря, який човни та судна використовують для проходу до міста, якщо робота подібних же споруд буде зупинена в будь-якій їх частині надзвичайними подіями на морі, та особа, щуо бажає подати прохання до короля, щзоб спорудити новий канал та зупинити старий ... повинна спочатку клопотати про отримання припису ad quаd dатпит, щоб встановити, якої шкоди буде заподіяно королю та іншим особам» ${ }^{15}$. В юридичній літературі звертали увагу на те, що «[u]ей припис забезпечував гнучку процедуру, яка дозволяє здійснювати будівництво за умови, що забудовник відшкодує збитки особі, що зазнає економічної шкоди» ${ }^{16}$. Шкодою, яку зазнавали інші особи, була насамперед шкода земельним ділянкам. Така шкода полягала у вилученні земельної ділянки чи їі частини на якій мав бути розташовуваним канал; у одноразовому чи періодичному затопленні земельної ділянки тощо. Таким чином, припис ad quad damnum був інструментом, що дозволяв здійснювати шкідливу діяльність, встановлюючи при цьому обов'язки особи, яка здійснює такі роботи, мінімізувати чи відшкодувати таку шкоду.

На думку Д. Холдер, процедура видачі припису «ad quod damnum» містить «... всі імпульси для сучасних форм екологічної оцінки: попередження, баланс протилежних інтересів, прочесуальн[у] справедливість так само як і керівні принципи сучасного екологічного мислення, такі, як збереження природи, визначення суспільної користі, а також надання повноважень та заохочення громадськості, використовуючи інстиmут представників громадськості» 17 . Однак «екологічна» складова цього припису була лише «імпульсами», що лише з часом перетворилися на оцінку впливу на довкілля, що відома сьогодні у більшості країн Європи. У XV-XVIII ст. ст. припис «ad quod damnum» був спрямований на забезпечення використання земель, ідея ж про те, що потрібно охороняти землю, оскільки вона $є$ природною цінністю, була невластива тогочасному суспільству (вільне тлумачення 18 ).

Таким чином, припис «ad quod damnum» був покликаний забезпечити реалізацію права власності та права користування земельними ділянками від порушень, що могли б виникнути у разі будівництва суспільно-важливих об’єктів.

\section{Процедури, у ході яких встановлюють умови здійснення екологічно безпечної діяльності у США}

Значна частина процедур прийняття рішень, які передбачали участь громадськості і в ході яких встановлювалися умови екологічно шкідливої діяльності, з'явилася вперше в США. У зв'язку з цим для поглиблення розуміння ролі цих процедур у механізмі реалізації і захисту прав людини та ії співвідношення з правом власності на земельні ділянки потрібно звернутися до аналізу судової практики США.

Розглянемо порядок участі громадськості у процесі прийняття адміністративних рішень у США на прикладі Штату Нью-Джерсі. У зазначеному штаті склалася така система участі громадськості у процесі прийняття рішень. $Є$ громадські слухання, «... які є адміністративними слуханнями, що не передбачають змагальності між сторонами, у присутності представника чи представників ... [органів виконавчої влади], яке забезпечує можливість для громадськості коментувати, але не включає в себе можливості оскарження» ${ }^{19}$. Право брати участь у таких громадських слуханнях мають всі заінтересовані особи (включно з власниками, земельним ділянкам яких буде завдано шкоди) ${ }^{20}$.

На відміну від наведених вище громадських слухань, є так звані змагальні громадські слухання (trialtype hearing). Право брати у таких громадських слуханнях мають лише особи, конституційне чи статутне право яких буде обмежене в результаті видачі дозволу. Пункт 3(а) розділу 14В-9 титулу 52 Адміністративного кодексу Штату Нью-Джерсі21 забороняє органам влади штату приймати нормативно-правові акти, які дозволяють іншим особам, крім заявника, оскаржувати рішення про видачу дозволу. Виняток з правила встановлений у п. 3(b) розділу 14В-9 титулу 52 Адміністративного кодексу Штату Нью-Джерсі22, який сформульовано так: «[n]оложення цього пункту не можуть тлумачитися як такі, що скасовують чи іншим чином обмежують будь-яке конституиійне чи таке, що передбачено статутами, право особи оскаржити рімення про видачу дозволу». У судовій практиці штату Нью-Джерсі ці положення тлумачаться так: якщо не передбачено статутом права на змагальні громадські слухання (trial-type hearing), скаржники повинні показати, що вони мають «особливий майновий інтерес, що є достатньо важливим, щоб вимагати слухань на підставі конституиіï» ${ }^{23}$. Право на змагальні громадські слухання (trial-type hearing), мають не лише особи, які мають особливий майновий інтерес, а й особи, які зазнають обмеження інших майнових прав у результаті прийняття рішення про видачу дозволу. 
Третяк Т.О. Процедури участі громадськості у прийнятті рішень щодо видів діяльності, що мають...

\section{Правове регулювання участі громадськості у процедурах прийняття рішень, що можсть негативно впливати на довкілля в Украйні}

Останнім часом відбулися істотні зміни у правовому регулюванні участі власників земельних ділянок у процедурах видачі дозволів, видача яких може спричинити істотний впливу на них. Зазначені зміни були внесені Законом України «Про оцінку впливу на довкілля» від 23 травня 2017 р. № 2059-VIII24 та Законом України «Про стратегічну екологічну оцінку» від 20 березня 2018 р. № 2354-VIII25.

Загальною рисою нормативно-правового регулювання порядку участі власників земельних ділянок у процедурах видачі дозволів є законодавче встановлення лише обов'язку враховувати коментарі та зауваження таких власників, без конкретизації того, чи повинен уповноважений видавати дозвіл орган лише зібрати і вивчити подану інформацію, чи громадське обговорення в України подібне до змагальних громадських слухань у США, в ході якого уповноважений видавати дозвіл орган повинен прийняти рішення про обмеження права власності.

Обов’язок органів, уповноважених видавати дозволи, приймати рішення про видачу такого дозволу обгрунтовано, добросовісно, розсудливо та пропорційно випливає 3 положень частини другої ст. 2 Кодексу адміністративного судочинства України від 06 липня 2005 р. № 2747-IV (далі - КАС). Згідно 3 цією частиною «[у] справах щзодо оскарження рішень, дій чи бездіяльності суб' єктів владних повноважень адміністративні суди перевіряють, чи прийняті (вчинені) вони: ... обтрунтовано, тобто з урахуванням усіх обставин, щзо мають значення для прийняття рішення (вчинення дії) ... безсторонньо (неупереджено); ... добросовісно; ... розсудливо; ... пропориійно, зокрема з дотриманням необхідного балансу між будь-якими несприятливими наслідками для прав, свобод та інтересів особи і иілями, на досягнення яких спрямоване ие рішення (дія)».

На перший погляд, ця стаття встановлює коло критеріїв, на предмет яких суд має перевіряти рішення органів виконавчої влади чи органів місцевого самоврядування під час розгляду справи адміністративної юрисдикції. В юридичній літературі було висловлено думку про те, що вимоги наведені у ст. 2 КАС є вичерпний переліком обставин, які суд повинен перевірити під час розгляду справ щодо оскарження рішень суб'єктів владних повноважень ${ }^{26}$. Якщо рішення про видачу дозволу не відповідає зазначеним вище вимогам і водночас порушує права позивача, суд зобов'язаний скасувати таке рішення. Частина 2 ст. 2 КАС зобов'язує суд застосовувати санкцію - скасування рішення про видачу дозволу, якщо таке рішення не відповідає зазначеним вище вимогам. Встановлення будь-якої санкції приводить до виникнення прав та обов'язків. Наприклад, правило про те, що рішення про видачу дозволу має бути скасованим, якщо воно є необгрунтованим, означає обов'язок приймати таке рішення обгрунтовано i, відповідно, право заявника на те, що рішення про видачу йому дозволу було обгрунтованим ${ }^{27}$.

Пункти 3 та 8 частини другої ст. 2 КАС містять також пояснення того, що означає обгрунтованість і пропорційність рішень. Зокрема, обгрунтованим є рішення, що прийняте «... урахуванням усіх обставин, щзо мають значення для прийняття рішення (вчинення діï)» (п. 3 частини другої ст. 2 КАС). У випадку 3 прийняттям рішення про видачу дозволу, що буде дозволяти негативний вплив на земельну ділянку, це положення означає що орган, уповноважений приймати рішення про видачу дозволу, має встановити такі обмеження на використання земельної ділянки (або іншими словами дозволити такий вплив), з урахуванням усіх обставини, що мають значення для цього рішення.

Пункт 8 частини другої ст. 2 КАС містить пояснення пропорційності рішення. Згідно 3 цим пунктом пропорційним буде рішення органу публічної адміністрації, яке прийняте «... з дотриманням необхідного балансу між будь-якими несприятливими наслідками для прав, свобод та інтересів особи і цілями, на досягнення яких спрямоване иее рішення (дія)». Метою, наприклад, дозволу на викиди забруднювальних речовин $\epsilon$ попередження забруднення довкілля та негативного впливу на здоров'я людей. Саме така мета зазначеного дозволу випливає $з$ положення частини першої ст. 11 Закону України «Про охорону атмосферного повітря» від 16 жовтня 1992 р. № 2707-ХІІ28, згідно з якою регулювання викидів найбільш поширених небезпечних забруднювальних речовин здійснюється «[д]ля забезпечення екологічної безпеки, створення сприятливого середовища життєдіяльності, запобігання шкідливому впливу атмосферного повітря на здоров'я людей та навколишнє природне середовище ...». У частині п’ятій ст. 11 зазначеного закону говориться про дозвіл на викиди. Назва ст. 11 Закону України «Про охорону атмосферного повітря» «Регулювання викидів забруднювальних речовин в атмосферне повітря стаціонарних джерел» свідчить про те, що всі інструменти, передбачені цією статтею, належать до регулювання викидів забруднювальних речовин в атмосферне повітря стаціонарних джерел, а отже, мета такого регулювання, визначена у частині першій ст. 11 зазначеного закону, $є$ метою і дозволу на викиди забруднювальних речовин. Забезпечення екологічної безпеки та створення сприятливого середовища життєдіяльності, поряд 3 іншими означають попередження невиправданого забруднення земельної ділянки. У зв'язку з цим баланс між правами та метою, на досягнення якого спрямовано дозвіл, означає справедливий баланс між ступенем обмеження права на здійснення підприємницької діяльності, що здійснюється з використанням шкідливого устаткування і потребує дозволу, та ступенем обмеження права власності на земельну ділянку.

На наш погляд, навіть якби положення частини другої ст. 2 КАС і не було б, то орган, уповноважений видавати дозвіл, повинен був би встановлювати умови такого дозволу так, щоб вони забезпечували розумний баланс між правом власності на земельну ділянку і правом власності на промислове устаткування. Такий обов'язок дозвільного органа безпосередньо випливає 3 положень Конституції України від 28 червня 1996 р. ${ }^{29}$ та Цивільного кодексу України від 16 січня 2003 р. № 435-IV30 (далі - ЦК) про право власності. Зок- 
рема, частина перша ст. 41 Конституції України фіксує право кожного «... володіти, користуватися $і$ розпоряджатися своєю власністю ...». Близьке за змістом правило до наведеного вище правила закріплене і у частині першій ст. 319 ЦК.

Частини четверта ст. 41 Конституції України закріплює гарантії права власності. Згідно 3 цією частиною «[н]іхто не може бути протиправно позбавлений права власності. Право приватної власності є непорушним». На наш погляд, перше речення цієї частини означає не лише заборону протиправного позбавлення права власності, а й заборону протиправного обмеження такого права, адже обмеження можуть бути наскільки суттєвими, що можуть призводити практично до припинення самого права власності. Навіть якщо обмеження не призводять до неможливості реалізації права власності, то логічним продовженням заборони протиправного позбавлення права власності є заборона протиправного обмеження права власності. Підставою для такого висновку є мета заборони протиправного позбавлення права власності. Право власності дає свободу людині втілювати свою волю та організовувати зовнішній світ відповідно до своєї волі. Позбавлення права власності на певний об'єкт звужує таку свободу. Однак звуження такої свободи відбувається не лише у разі позбавлення права власності на такий об'єкт, а й внаслідок обмеження такого права, тому заборона протиправного позбавлення права власності логічно передбачає і заборону протиправного його обмеження. Рівність прав всіх людей (ст. 21 Конституції України) робить протиправним забезпечувати реалізацію права однієї особи, шляхом встановлення невиправданих обмежень для іншої.

Слід зазначити, що близька за змістом до частини четвертої ст. 41 Конституції України частина перша ст. 321 ЦК забороняє вже не лише протиправне позбавлення права власності, а й протиправне його обмеження.

Частина сьома ст. 41 Конституції України також, на наш погляд, є підставою для обов'язку дозвільного органа встановлювати умови дозволу на основі справедливого балансу між правами заявника та власника земельної ділянки, на яку буде впливати діяльність заявника. Згідно з частиною сьомою ст. 41 Конституції України «[в]икористання власності не може завдавати шкоди правам, свободам та гідності громадян, інтересам суспільства, погіршувати екологічну ситуацію і природні якості землі». Дуже близьке за змістом правило закріплене також і в частині п’ятій ст. 319 ЦК.

Текст частини сьомої ст. 41 Конституції України та частини п’ятої ст. 319 ЦК дає змогу припустити, що вони були орієнтовані саме на власників промислового устаткування, використання якого може погіршувати екологічну ситуацію чи природні якості землі. У зв'язку з цим зафіксована у згаданих статтях заборона дозвільному органові встановлювати невиправдано м'які умови для власників промислового обладнання, експлуатація якого спричинятиме забруднення сусідніх земельних ділянок, є досить очевидною. При цьому власник земельної ділянки, що відмовляється зазнавати виправданих обмежень свого права, перешкоджатиме (завдаватиме шкоди) реалізації права власності на промислове обладнання та земельну ділянку іншої особи. Обов'язок не завдавати шкоди правам, свободам та гідності громадян є одним із обов'язків, що фіксує частина сьома ст. 41 Конституції України та частина п’ята ст. 319 ЦК. Встановлення ж виправданих обмежень обох прав (права власності на промислове устаткування та права власності на земельну ділянку, яка буде зазнавати впливу) є єдиним можливим справедливим рішенням дозвільного органа у цій ситуації. Саме така ситуація і дає змогу стверджувати про те, що положення аналізованої частини є нормативно-правовим підгрунтями обов'язку дозвільного органа встановлювати виправдані обмеження для права заявника та власника земельної ділянки, на яку буде чинитися негативний вплив.

Обов'язок дозвільного органа встановлювати лише виправдані обмеження грунтується також на принципі добросовісності. В юридичній літературі було висловлено, на наш погляд, обгрунтовану думку, згідно 3 якою іманентною ознакою права є сприйняття іншої людини, іiї прав та інтересів, рівними своїм права та інтересам. Не визнання такого факту перетворює вимоги особи на свавілля і насильство. Збіг таких переконань багатьох людей утворює нормативну основу соціального життя і формується у вигляді абстрактних та стійких вимог до учасників правового спілкування. На індивідуальному рівні конформність таким принципам виражає поняття добросовісності 31 .

Дозвільний орган, що добросовісно встановлює умови дозволу, яким буде дозволено діяльність, що негативно впливає на чужу земельну ділянку, не може встановлювати невиправданих обмежень ні для заявника, ні для власника земельної ділянки, на яку буде спричинено вплив від діяльності, на здійснення буде видано дозвіл.

Хоча принцип добросовісності встановлений як п. 5 частини другої ст. 2 КАС, так і п. 6 частини першої ст. 3 ЦК, проте цей принцип, будучи умовою існування права взагалі, застосовувався навіть тоді, коли б ст. 2 КАС та ст. 3 ЦК і не було б.

На наш погляд, наведені вище положення Конституції України, ЦК та КАС є основними, які фіксують обов'язок дозвільного органа встановлювати лише виправдані обмеження для права власності осіб, на яких буде спричинено вплив дозволеною діяльністю. В Україні прийнято низку законів, які зобов’язують дозвільний орган враховувати зауваження і коментарі громадськості під час прийняття адміністративних рішень. На наш погляд, ці нормативно-правові акти нічого не змінюють у закріпленому у вищезазначених нормативно-правових актах обов'язку дозвільного органа чи іншого органа публічної адміністрації встановлювати лише обгрунтовані обмеження права власності на земельну ділянку та інших прав. Положення нормативноправових актів, про які буде йтися нижче, повинні тлумачитися у системі із вище проаналізованими положеннями Конституції України, ЦК та КАС. Ми наводимо ми ці положення, оскільки вони є додатковим під- 
твердження того, що документи дозвільного характеру та інші адміністративні рішення є засобами формування правил добросусідства, а участь заінтересованої громадськості (включно 3 власниками земельної ділянки, на яку буде спричинено вплив від дозволеної діяльності) у процесі їх прийняття - участю у встановленні правил добросусідства.

Одним із законів, положення якого зобов'язує враховувати заперечення та коментарі громадськості, отримані в ході процедур прийняття адміністративних рішень, є Закон України «Про звернення громадян» від 02 жовтня 1996 р. № 393/96-ВР32. Частина перша ст. 20 цього документа містить припис, згідно 3 яким «[3]вернення розглядаються і вирішуються у термін не більше одного місяия від дня їх надходження, а ті, які не потребують додаткового вивчення, - невідкладно, але не пізніше п'ятнадияти днів від дня їх отримання». Слід звернути увагу, що ця норма фіксує обов'язок не лише розглянути звернення, а й вирішити його. Вирішити звернення означає задовольнити його, якщо воно є виправданим. Право органа, зобов'язаного розглядати звернення громадян, не слідувати необгрунтованим зверненням громадян випливає 3 положення п. 3 частини другої ст. 2 КАС, у системі з яким і має тлумачитися положення частини першої ст. 20 Закону України «Про звернення громадян».

Частина друга ст. 11 Закону України «Про оцінку впливу на довкілля» містить обов'язок органів державної влади та органів місцевого самоврядування, які приймають рішення про провадження планованої діяльності, врахувати висновок з оцінки впливу на довкілля. Частина третя ст. 9 цього ж закону зобов'язує органи, уповноважені видавати висновок з оцінки впливу на довкілля (далі - висновок з ОВД) під час видання цього висновку брати до уваги звіт з оцінки впливу на довкілля та звіт про громадське обговорення. Згідно 3 другим реченням частини сьомої ст. 7 Закону України «Про оцінку впливу на довкілля» невід'ємною частиною звіту про громадське обговорення є протоколи громадських слухань, усі отримані письмові зауваження і пропозиції громадськості, а також таблиця із зазначенням інформації про повне врахування, часткове врахування або обгрунтоване відхилення отриманих під час громадського обговорення зауважень та пропозицій.

Висновок з ОВД містить обов'язкові до виконання екологічні умови здійснення планованої діяльності (частина друга ст. 9 Закону України «Про оцінку впливу на довкілля»). Таким чином, екологічні умови висновку з ОВД уповноважений орган повинен формувати з урахування зауважень і пропозицій громадськості (включно з власниками земельних ділянок, на яку буде спричинятися вплив від планованої діяльності). Причому обов'язок уповноваженого органа, що видає висновок з ОВД, брати до уваги зауваження i коментарі громадськості повинен тлумачитися у системі із вищенаведеними положеннями Конституції України, ЦК та КАС, що не зобов’язують встановлювати лише виправдані обмеження прав як особи, яка планує здійснювати шкідливу діяльність, так і власника земельної ділянки, на яку буде спричинено вплив.

Обов'язок враховувати зауваження і коментарі громадськості передбачено також і Законом України «Про стратегічну екологічну оцінку». Цей закон регламентує порядок участі громадськості у процесі затвердження документів державного планування. До таких документів п. 3 частини першої ст. 1 цього закону включає «... стратегії, плани, схеми, містобудівна документачія, загальнодержавні програми, державні цільові програми та інші програми і програмні документи, включаючи зміни до них, які розробляються та/або підлягають затвердженню органом державної влади, органом місиевого самоврядування». Згідно 3 частиною п’ятою ст. 13 Закону України «Про стратегічну екологічну оцінку» «[у]сі зауваження $i$ пропозиції, одержані протягом встановленого у иій статті строку, підлягають обов'язковому розгляду замовником. За результатами розгляду замовник враховує одержані зауваження і пропозиції або мотивовано їх відхиляє». Як і у випадку із порядком врахування зауважень і коментарів громадськості, який передбачений Законом України «Про оцінку впливу на довкілля», положення частини п’ятої ст. 13 Закону України «Про стратегічну екологічну оцінку» слід тлумачити у системі зі ст. ст. 21, 41 Конституції України, ст. ст. 319, 321 ЦК та частиною другою ст. 2 КАС.

На те, що процедура участі громадськості є процедурою формування умов добросусідства, вказують також і положення законодавства України та їі міжнародних договорів. Зокрема, Конвенція про доступ до інформації, участь громадськості в процесі прийняття рішень та доступ до правосуддя 3 питань, що стосуються довкілля від 25 червня 1998 р. ${ }^{33}$ (далі - Оргуська конвенція) передбачає три основних інструменти громадськості, які їі представники можуть використовувати для захисту своїх екологічних інтересів. До цих інструментів належать: доступ до екологічної інформації, участь громадськості у прийнятті екологічно важливих рішень, доступ до правосуддя. Участі громадськості у процесі прийняття екологічно важливих рішень присвячена ст. 6 Оргуської конвенції. Стаття 1 Оргуської конвенції зазначає, що «[з] метою сприяння захисту права кожної людини нинішнього і прийдешніх поколінь жити в довкіллі, сприятливому для ї̈ здоров'я та добробуту, кожна зі Сторін гарантує права на доступ до інформачиї, на участь громадськості в прочесі прийняття рішень $і$ на доступ до правосуддя з питань, шзо стосуються навколишнього середовища, відповідно до положень цүієї Конвенції». Таким чином, метою, заради якої надано представникам громадськості право на участь у процесі прийняття рішень, є забезпечення права кожного жити у сприятливому довкіллі. Саме на таке призначення наведених вище трьох прав звернув увагу Комітет з дотримання Оргуської конвенції у своїх висновках щодо дотримання в Україні положень цієї конвенції, зокрема у пункті 36 Висновку Комітету з дотримання щодо виконання в Україні обов'язків, передбачених Оргуською конвенцією у справі глибоководного судного каналу «Бистре» від 18 лютого 2005 р. (ECE/MP.PP/C.1/2005/2/Add.3) 34 зазначаючи, що «... недотримання вимог у частині операційних положень Конвенщї [положень, що стосуються доступу 
до екологічної інформації, участі громадськості у прийнятті рішень та доступ до правосуддя] $\epsilon$ недотриманням також і в частин цілі Конвениії, як вона визначена у статті 1». Створення небезпечного довкілля означає, поряд з іншими, і неприйнятний негативний вплив на земельну ділянку і є порушенням правил добросусідства (порушенням права власності на земельну ділянку).

Підбиваючи підсумки, необхідно акцентувати увагу на основних висновках, що є наслідком проведеного дослідження.

1. Процедура участі громадськості у процесі видачі дозволів чи прийняття інших адміністративних рішень, що можуть мати негативний вплив на довкілля, є, поряд з іншим, також і процедурою, у якій формуються і затверджуються правила добросусідства.

2. Право власників земельних ділянок брати участь у процедурах громадського обговорення є логічним продовженням їх права власності на ці земельні ділянки, а сама процедура громадського обговорення - однією із форм реалізації права власності на земельні ділянки.

3. Власники, які беруть участь у процедурах видачі дозволів чи прийнятті інших адміністративних рішень, якими буде дозволено здійснювати діяльність, що негативно впливатиме на їх земельну ділянку, мають право на те, щоб орган, який приймає таке адміністративне рішення, встановив лише виправдані обмеження його права власності, а також має право, щоб такий орган встановив виправдані обмеження права здійснювати діяльність, що спричинятиме негативний вплив на його земельну ділянку. Порушення цього права є порушенням права власності на земельну ділянку і дає право звертатися до суду за його захистом.

${ }^{1}$ Екологічне право України: підручник для студ. вищ. навч. закладів / Гетьман А.П., Шульга М.В., Попов В.К. та ін. ; за ред. А.П. Гетьмана та М.В. Шульги. Харків: Право, 2006. 384 с.

2 Ерофеев Б.В. Экологическое право России: учебник. 8-е изд., испр. и доп. Москва: ООО Профобразование, 2001. 711 с.

3 Балюк Г.І. Екологічне право України: Конспект лекцій у схемах (Загальна і Особлива частини): навч. посіб. Київ: Юрінком Інтер, 2006. $192 \mathrm{c}$.

4 Земельне право України: підручник / Шульга М.В. (кер. авт. кол.), Анісімова Г.В., Багай Н.О, Гетьман А.П. та ін. ; за ред. Шульги М.В. Київ: Юрінком Інтер, 2004. 368 с.

5 Земельное право Украины: учеб. пособ. / Беженарь А.М., Бердников Е.С., Бондарь Л.А. и др.; под ред. Погребного А.А. и Каракаша И.И. Киев: Истина, 2002. 496 с.

${ }^{6}$ Мірошниченко А.М. Земельне право України: підручник. Київ: Алерта ; КНТ ; ЦУЛ, 2009. 712 с.

7 Бринчук М.М. Экологическое право (право окружающей среды): учебник для высших учебных заведений. Москва: Юристъ, 1999. С. 317-318.

8 Мірошниченко А.М. Земельне право України: підручник. Київ: Алерта ; КНТ ; ЦУЛ, 2009. С. 630.

9 Андрейцев В.І. Екологічне право: Курс лекцій: навч посібник для юрид. фак. і вузів. Київ: Вентурі, 1996. С. 95.

10 Кодлов В.А., Борякова С.А., Волкова Н.А. Негаторно-правовая защита вещных прав по российскому законодательству: монография. Москва: Изд-во СГУ, 2012. С. 107, 111.

11 William H. Rodgers, Jr. Environmental Law. Second edition. St. Paul: Wet Publishing CO., 1994. P. 112-113.

12 Steinway D.M. Chapter 1. Fundamentals of Environmental Law. Environmental Law Handbook / [Steinway D.M., Ewing K.A., Hutt J.B. and the others] / Editor Emeritus Thomas F.P. Sullivan. Lanham: Bernan Press, 2014. P. 17.

13 Bosselman F.P. Limitations Inherent in the Title of Wetlands at Common Law. Stanford Environmental Law Journal. 1996. Vol. 15(2). P. 292

${ }^{14}$ Holder J. Environmental Assessment. The regulation of Decision Making. Oxford: Oxford University Press, 2004. P. 4.

15 Viner C. A General Abridgment of Law and Equity, Alphabetically Digested and References to the Whole [the second edition]. Vol. II. London, 1791. P. 126.

16 Bosselman F.P. Limitations Inherent in the Title of Wetlands at Common Law. Stanford Environmental Law Journal. 1996. Vol. 15(2). P. 296.

17 Holder J. Environmental Assessment. The regulation of Decision Making. Oxford: Oxford University Press, 2004. P. 4.

18 Holder J. Environmental Assessment. The regulation of Decision Making. Oxford: Oxford University Press, 2004. P. 296.

${ }^{19}$ In re Freshwater Wetlands Statewide Gen. Permits, 185 N.J. 452, 472, 888 A.2d 441 (2006) Available at. URL: https://www. leagle.com/decision/20061329888a2d44121326 (last visited Sep. 15, 2019).

20 Там само.

212013 New Jersey Revised Statutes Title 52 - STATE GOVERNMENT, DEPARTMENTS AND OFFICERS Available at. URL: https://law.justia.com/codes/new-jersey/2013/title-52/section-52-14b-3.3/ (last visited Sep. 15, 2019).

22 Там само.

23 In re Freshwater Wetlands Statewide Gen. Permits, 185 N.J. 452, 472, 888 A.2d 441 (2006) Available at. URL: https://www. leagle.com/decision/20061329888a2d44121326 (last visited Sep. 15, 2019).

24 Про оцінку впливу на довкілля: Закон України від 23 травня 2017 р. № 2059-VIII. Відомості Верховної Ради Украӥни. 2017. № 29. Ст. 315.

25 Про стратегічну екологічну оцінку: Закон України від 20 березня 2018 р. № 2354-VIII. Відомості Верховної Ради України. 2018. № 16. Ст. 138.

26 Матвійчук В.К., Хар І.О. Науково-практичний коментар до Кодексу адміністративного судочинства України: в 2 т. 2-ге вид., змін. та доп. / за заг. ред. В.К. Матвійчука. Київ: Алерта, КНТ, 2008. Т. 1. С. 28-29.

27 Про те, що вимоги статті 2 КАС означає обов'язок органів публічної адміністрації, які приймають адміністративні рішення, вже зверталася увага в юридичній літературі, див.: Матвійчук В.К., Хар I.О. Науково-практичний коментар до Кодексу адміністративного судочинства України: в 2 т. 2-ге вид., змін. та доп. / за заг. ред. В.К. Матвійчука. Київ: Алерта, КНТ, 2008. T. 1. C. 30.

28 Про охорону атмосферного повітря: Закон України від 16 жовтня 1992 р. № 2707-XII. Відомості Верховної Ради України. 1992. № 50. Ст. 678. 
29 Конституція України від 28.06.1996 р. Відомості Верховної Ради України. 1996. № 30. Ст. 141.

30 Цивільного кодексу України від 16.01.2003 р. № 435-IV. Відомості Верховної Ради України. 2003. № 40-44. Ст. 356.

31 Вільне тлумачення думки висловленої у роботі: Дождев Д.В. Добросовесность (bona fides) как правовой принцип. Политико-правовые иенности: история и современность. Москва Эдиториал УРСС, 2000. С. 97-98. Ст. 256.

32 Про звернення громадян: Закон України від 02.10.1996 р. № 393/96-ВР. Відомості Верховної Ради України. 1996. № 47.

33 Конвенція про доступ до інформації, участь громадськості в процесі прийняття рішень та доступ до правосуддя 3 питань, що стосуються довкілля, укладена 25.06.1998 р., підписана від імені України 25.06.1998, ратифікована Законом України від 06.07.1999 р. № 832-XIV. URL: https://www.unece.org/fileadmin/DAM/env/pp/documents/cep43ukr.pdf (дата звернення: 13.09.2019).

34 Findings and recommendations with regard to compliance by Ukraine with the obligations under the Aarhus Convention in the case of Bystre deep-water navigation canal construction (submission ACCC/S/2004/01 by Romania and communication ACCC/C/2004/03 by Ecopravo-Lviv (Ukraine)) Adopted by the Aarhus Convention's Compliance Committee on 18 February 2005. URL: https://www. unece.org/fileadmin/DAM/env/documents/2005/pp/c.1/ece.mp.pp.c1.2005.2.Add.3.e.pdf (last visited September 13, 2019).

\section{References:}

2013 New Jersey Revised Statutes Title 52 - STATE GOVERNMENT, DEPARTMENTS AND OFFICERS. URL: https://aw.jus tia.com/codes/new-jersey/2013/title-52/section-52-14b-3.3/ [in English].

Bosselman, F.P. (1996) Limitations Inherent in the Title of Wetlands at Common Law Stanford Environmental Law Journal. 15(2), 292, 296 [in English].

Findings and recommendations with regard to compliance by Ukraine with the obligations under the Aarhus Convention in the case of Bystre deep-water navigation canal construction (submission ACCC/S/2004/01 by Romania and communication ACCC/C/2004/03 by Ecopravo-Lviv (Ukraine)) Adopted by the Aarhus Convention's Compliance Committee on 18 February 2005. URL: https://www.unece.org/fileadmin/DAM/env/documents/2005/pp/c.1/ece.mp.pp.c1.2005.2.Add.3.e.pdf [in English].

Holder, J. (2004) Environmental Assessment. The regulation of Decision Making. Oxford: Oxford University Press [in English].

In re Freshwater Wetlands Statewide Gen. Permits, 185 N.J. 452, 472, 888 A.2d 441 (2006). URL: https://www.leagle.com/deci sion/20061329888a2d44121326 [in English].

Steinway, D.M., Ewing, K.A., Hutt, J.B. and the others (2014) Chapter 1. Fundamentals of Environmental Law. Environmental Law Handbook (Editor Emeritus Thomas F.P. Sullivan. Lanham): Bernan Press [in English].

Viner, C. (1791) A General Abridgment of Law and Equity, Alphabetically Digested and References to the Whole. Vol. II. London [in English].

William, H., Rodgers, Jr. (1994) Environmental Law. St. Paul: Wet Publishing CO.

Andrejcev, V. I. (1996) Ekologichne pravo. Kyiv: Venturi [in Ukrainian].

Balyuk, G. I. (2006) Ekologichne pravo Ukrayiny: Konspekt lekcij u sxemax (Zagal’na i Osoblyva chastyny'). K.: Yurinkom Inter [in Ukrainian].

Bogolyubov, S. A. (1999) Ekologicheskoe pravo. M.: Izdatel`skaya gruppa NORMA-Y`NFRA M [in Russian]

Brinchuk, M. M. (1999) Ekologicheskoe pravo (pravo okruzhayushchej sredy). M.: Yurist [in Russian].

Dozhdev, D. V. (2000) Dobrosovesnost' (bona fides) kak pravovoj princip. Politiko-pravovye cennosti: istoriya i sovremennost'.

M.: Editorial URSS, 97-98 [in Russian].

Get'man, A. P., Shul'ga, M. V., Popov, V. K. ta in. (2006) Ekologichne pravo Ukrainy. Harkiv: Pravo [in Ukrainian].

Erofeev, B. V. (2001) Ekologicheskoe pravo Rossii. M.: OOO Profobrazovanie [in Russian].

Zakon Ukrainy «Pro zvernennya gromadyan» vid 02.10.1996 № 393/96-VR (1996) Vidomosti Verkhovnoi Rady Ukrainy. 47, 256 [in Ukrainian].

Zakon Ukraïni «Pro ohoronu atmosfernogo povitrya» vid 16.10.1992 № 2707-HII (1992) Vidomosti Verkhovnoi Rady Ukrainy. 50,678 [in Ukrainian].

Zakon Ukraïni «Pro ocinku vplivu na dovkillya» vid 23.05.2017 № 2059-VIII (2017) Vidomosti Verkhovnoi Rady Ukrainy. 29, 315 [in Ukrainian].

Zakon Ukraïni «Pro strategichnu ekologichnu ocinku» vid 20.03.2018 № 2354-VIII (2018) Vidomosti Verkhovnoi Rady Ukrainy. 16, 138 [in Ukrainian].

Shul'ga, M.V., Anisimova, G.V., Bagaj, N.O., Get'man, A.P. ta in. (za red M.V. Shul'gi) (2004) Zemel'ne pravo Ukrainy. K.: Yurinkom Inter [in Ukrainian].

Bezhenar', A.M., Berdnikov, E.S., Bondar', L.A. i dr. (pod red. A.A. Pogrebnogo i I.I. Karakasha) (2002) Zemel'noe pravo Ukrainy. K.: Istina [in Ukrainian].

Kodlov, V.A., Boryakova, S.A., Volkova, N.A. (2012) Negatorno-pravovaya zashchita veshchnyh prav po rossijskomu zakonodatel'stvu. M.: Izd-vo SGU [in Russian].

Konvenciya pro dostup do informaciï, uchast' gromads'kosti v procesi prijnyattya rishen' ta dostup do pravosuddya z pitan', shcho stosuyut'sya dovkillya, ukladena 25.06.1998, pidpisana vid imeni Ukrainy 25.06.1998, ratifikovana Zakonom Ukrainy vid 06.07.1999 № 832-XIV. URL: https://www.unece.org/fileadmin/DAM/env/pp/documents/cep43ukr.pdf [in Ukrainian].

Konstituciya Ukrainy vid 28.06.1996 (1996) Vidomosti Verkhovnoi Rady Ukrainy. 30, 141 [in Ukrainian].

Matvijchuk, V.K. \& Har I.O. (2008) Naukovo-praktichnij komentar do Kodeksu administrativnogo sudochinstva Ukraïni. V 2-h tt.

Tom. 1. K.: Alerta, KNT [in Ukrainian].

Miroshnichenko, A.M. (2009) Zemel'ne pravo Ukrainy. K.: Alerta ; KNT ; CUL Civil'nij kodeks Ukraïni vid 16.01.2003 № 435-IV (2003) Vidomosti Verhovnoi Rady Ukrainy. 40-44, 356 [in Ukrainian].

\section{Резюме}

Третяк Т.О. Процедури участі громадськості у прийнятті рішень щодо видів діяльності, що мають або можуть мати негативний вплив на довкілля як засоби встановлення правил добросусідства.

Досвід застосування процедур участі громадськості у процесі прийняття рішень, які дозволяють і встановлюють умови для здійснення екологічно-шкідливої діяльності, свідчить, що їх потенціал залишається не достатньо використаним. Належне 
використання цих процедур дасть змогу підвищити ефективність охорони права власності від порушень, що є результатом негативного впливу від промислового устаткування, а також запобігти зайвим витратами, які змушені нести підприємці у зв'язку з конфліктами з громадськістю, що зазнає негативного впливу від експлуатації екологічно шкідливого устаткування.

Автор статті ставить за мету дослідити правову природу процедур участі громадськості у зазначених процедурах, що дасть змогу більш повно використовувати їх потенціал.

Ключові слова: право власності на земельну ділянку; обмеження права власності на земельну ділянку; реалізація права власності на земельну ділянку; захист права власності на земельну ділянку; правила добросусідства; процедури видачі документів дозвільного характеру.

\section{Резюме}

Третяк Т.A. Процедуры участия общественности в принятии решений относительно видов деятельности, которые имеют или могут иметь отрицательное влияние на окружающую среду как средства установления правил добрососедства.

Опыт применения процедур участия общественности в процессе принятия решений, позволяющих и устанавливающих условия осуществления экологически вредной деятельности, свидетельствует, что их потенциал остается недостаточно использованным. Надлежащее использование этих процедур позволит повысить эффективность охраны права собственности от нарушений, являющихся результатом негативного воздействия промышленных установок, а также избежать лишних издержек, нести которые должны предприниматели в связи с конфликтами с общественностью, испытывающей негативное влияние от эксплуатации экологически-вредных установок.

Автор статьи ставит своей целью исследовать правовую природу процедур участия общественности в указанных процедурах, что позволит более полно использовать их потенциал.

Ключевые слова: право собственности на земельный участок; ограничения права собственности на земельный участок; реализация права собственности на земельный участок; защита права собственности на земельный участок; правила добрососедства; процедуры выдачи документов разрешительного характера.

\section{Summary}

Taras Tretiak. The Public Participation in Decision-Making Process on the Types of Activities Having or are Likely to Have an Adverse Impact on the Environment as Means of Establishing Land Ownership Limitations in the Neighbours' Interests.

The Ukrainian legislation governing the public participation in making the decisions allowing and setting the conditions for the environmentally harmful activity was essentially amended recently. These procedures implementation experience demonstrates that their potential is not used properly neither by the persons planning to carry out the environmentally harmful activity, no by the persons, that are negatively affected by this activity. Proper use of these procedures allows to improve protection of the land ownership infringed by industrial installations negative impact and to avoid pointless expenditures, which entrepreneurs have to bear because of the conflicts with the public, affected by the environmentally harmful installation exploitation.

The author of this article sets the task to study the public participation in the mentioned procedures legal nature, this study will allow to benefit more fully of these procedures' potential.

As a result of research carried out in this article, the author draws the following conclusions.

The public participation in the permitting procedure or the taking the others administrative decisions procedure for the installation having or are likely to have adverse impact on the environment, among the others, are the procedures in which the limitations on land ownership are established.

The land owners right to participate in decision-making procedures is their land ownership logical extension, the public participation in decision-making procedure is one the forms of the land ownership implementation.

The land owners participating in decision-making procedures of the permitting documents allowing to carry out the activity having or is likely to have adverse impact on their land parcel have the right that public authority taking these decisions establishes only reasonable limitations of their land ownership and have also the right that this public authority imposes reasonable restrictions on the other person's right to exercise the activity having or is likely to have adverse impact on their land parcels. This right violation is the land ownership violation and entitles the person, whose right have been violated, to appeal to the court for the protection.

Key words: the land ownership; the land ownership restrictions; the land ownership realization; the land ownership protection; the good neighbourliness rules; the permitting procedure. 